\title{
Immunohistochemical analysis of medullary breast carcinoma autoantigens in different histological types of breast carcinomas
}

\author{
Olga Kostianets ${ }^{1,2^{*}}$, Stepan Antoniuk ${ }^{3}$, Valeriy Filonenko ${ }^{1}$ and Ramziya Kiyamova ${ }^{1}$
}

\begin{abstract}
Background: On the past decade a plethora of investigations were directed on identification of molecules involved in breast tumorogenesis, which could represent a powerful tool for monitoring, diagnostics and treatment of this disease. In current study we analyzed six previously identified medullary breast carcinoma autoantigens including LGALS3BP, RAD50, FAM50A, RBPJ, PABPC4, LRRFIP1 with cancer restricted serological profile in different histological types of breast cancer.
\end{abstract}

Methods: Semi-quantitative immunohistochemical analysis of 20 tissue samples including medullary breast carcinoma, invasive ductal carcinoma, invasive lobular carcinoma and non-cancerous tissues obtained from patients with fibrocystic disease (each of five) was performed using specifically generated polyclonal antibodies. Differences in expression patterns were evaluated considering percent of positively stained cells, insensitivity of staining and subcellular localization in cells of all tissue samples.

Results: All 6 antigens predominantly expressed in the most cells of all histological types of breast tumors and non-cancerous tissues with slight differences in intensity of staining and subcellular localization. The most significant differences in expression pattern were revealed for RAD50 and LGALS3BP in different histological types of breast cancer and for PABPC4 and FAM50A antigens in immune cells infiltrating breast tumors.

Conclusions: This pilot study made possible to select 4 antigens LGALS3BP, RAD50, PABPC4, and FAM50A as promising candidates for more comprehensive research as potential molecular markers for breast cancer diagnostics and therapy.

Virtual slides: The virtual slides' for this article can be found here: http://www.diagnosticpathology.diagnomx.eu/ vs/1860649350796892

Keywords: Tumor-associated antigen, Expression pattern, Breast cancer

\section{Background}

Breast cancer is the most common female cancer in the world, with high mortality rate [1,2]. Identification of biomarkers for early detection and new therapeutic targets of breast cancer helps to continuously reduce the morbidity of this frequent pathology in women. This entails resolving the physiological, cellular and molecular processes underlying the complexity of breast tumor

\footnotetext{
* Correspondence: kostjanez@ukr.net

'Department of Cell Signaling, Institute of Molecular Biology and Genetics,

NAS of Ukraine, 150, Zabolotnogo str., Kyiv, Ukraine

'Educational and Scientific Centre "Institute of Biology", Taras Shevchenko

National University of Kyiv, 64, Volodymyrs'ka Str., Kyiv, Ukraine

Full list of author information is available at the end of the article
}

development and associated tumor heterogeneity [3]. In recent years efforts of many researchers are focused on search of new markers and molecules involved in breast tumorogenesis, which could be used in disease diagnostics, treatment and prognosis.

Development and application of proteomic technologies based on detection of autoantibodies to tumor antigens, including serological identification of antigens by recombinant expression cloning (SEREX) [4-6], serological proteome analysis (SEPRA) [7-9], multiple affinity protein profiling (MAPPing) [10] and high-density protein microarrays [11] have lead to identification of multiply biomarkers of breast cancer inducing autoantibody

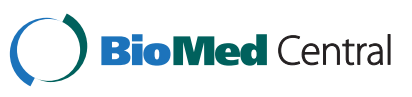


response. The characterization of tumor markers remains a major goal in both understanding the cellular mechanisms associated with tumorogenesis and in developing targets for the molecular therapy and diagnostics of cancer.

Protein tumor marker reflects consistent, biologically relevant changes in the tumor. It has been described that numerous autologous proteins of tumor cells, generally known as tumor-associated antigens (TAAs), can elicit humoral immune response in cancer patients as a result of their aberrant expression [12], alternative splicing of pre-messenger RNAs [13], point mutations [14], aberrant localization, folding [15], degradation [16] and/or post-translation alteration $[17,18]$. Many breast cancer antigens have been reported to be overexpressed at protein level in breast tumors; these include MUC1 [19], HER2/neu [20], P53 [21], HSP-27 [22,23], GIPC-1 [24], fibulin 1 [25] and cyclins B1 [26], D1 [27] and E [28]. Some tumor markers, for example, cyclin B1 also was found to change its location in cancer cells and localized predominantly in the cytosol [29], while normally it presents in the nucleus.

Our previous study was focused on identification of novel TAAs of medullary breast carcinoma (MBC), a relatively rare type of ductal carcinoma, which despite anaplastic features has favorable prognosis for patients [30-32]. High lyphocytic infiltration, indicating possible presence of specific antigen within tumor lesion is a distinctive feature of medullary breast carcinoma $[30,33,34]$. Using SEREX approach and serological plaquespot assay we identified 41 potential antigens of medullary breast carcinoma, and showed that 18 of them had cancer restricted serological profile [35]. In this study protein expression pattern of a small subset of 6 from 18 (lectin, galactoside-binding, soluble, 3 binding protein (LGALS3BP); human RAD50 S. cerevisiae homolog (RAD50); family with sequence similarity 50, member A (FAM50A); poly(A) binding protein cytoplasmic 4 (PABPC4); recombination signal binding protein for immunoglobulin kappa J region (RBPJ) and leucine rich repeat (in FLII) interacting protein 1 (LRRFIP1)) antigens was investigated by immunohistochemical analysis of different histological types of breast cancer and non-cancerous breast tissues from patients with fibrocystic disease. Semiquantitative analysis of positively stained cells, considering intensity of staining, and subcellular localization in normal, cancer and immune cells of lymphocytic infiltrate presented in some tumors using specifically generated polyclonal antibodies have been performed.

\section{Methods}

\section{Clinicopathological data}

Fresh breast cancer and non-cancerous breast tissue (NCT) samples were obtained from 15 female patients
(39-75 years) with primary breast carcinoma and 5 patients with fibrocystic disease (37-50 years) correspondingly, who underwent surgery in the Dnipropetrovsk Clinical Oncological Center (Dnipropetrovsk, Ukraine) between 2008 and 2010. Surgical specimens were fixed with $10 \%$ buffered formalin, and paraffin embedded sections were stained with hematoxilin and eosin. All the tissue sample sections were reviewed to confirm the original diagnosis by an expert pathologist. The clinical and histopathological characteristics of these patients are shown in Table 1. Breast cancer cases included invasive ductal carcinoma (IDC) $(n=5)$, invasive lobular carcinoma (ILC) $(\mathrm{n}=5)$, and medullary carcinoma $(n=5)$. Clinicopathological data were obtained from patient medical records and from the files kept at the Department of Pathohistology of Dnipropetrovsk Clinical Oncological Center. The study was approved by the Ethics Committee of the Institute of Molecular Biology and Genetics, NAS of Ukraine and informed consent was obtained from all patients.

\section{Cloning, expression and purification of recombinant proteins}

Specific cDNA of LGALS3BP, RAD50, FAM50A, RBPJ, PABPC4 and LRRFIP1 genes, isolated from MBC cDNA library Br502, was cloned into pGEX4T3 and/or pET28b expression vectors, containing glutathione-S-transferaseand 6His-tags respectively (Table 2). Expression of fused recombinant proteins was induced by $1 \mathrm{mM}$ IPTG at $37^{\circ} \mathrm{C}$ for $4 \mathrm{~h}$ in E.coli BL21 (DE3) pLysE cells transformed by correspondent recombinant plasmids. Proteins were affinity purified using GST-sepharose and Ni-NTA-agarose according to manufacturers' protocols. Some expressed recombinant proteins were present in the inclusion bodies of the pellet, which were washed before the purification procedure according X.A. Yang protocol [36]. Purity of proteins was analyzed by SDSPAGE. All proteins were dialyzed against phosphate buffered saline (PBS), pH7.4, and then were used for immunization of mice.

\section{Generation of polyclonal antibodies}

Polyclonal antibodies against LGALS3BP, RAD50, FAM50A, RBPJ, PABPC4 and LRRFIP1 autoantigens were generated according the protocol described below. A primary dose of $20 \mathrm{mkg}$ of each recombinant polypeptide was solubilized in Freund's complete adjuvant (Sigma, Aldrich, Germany) and administered intraperitoneally in six- to 8-week-old female BALB/c mice four times at 2-week intervals. Then, immunized mice (with serum titer no less than $10^{5}-10^{6}$ ) were boosted with $20 \mathrm{mkg}$ of antigen in PBS by intraperitoneal injection. After 3 days of the booster injection, blood was collected from the mice, and the serum was separated. 
Table 1 Characteristics of patients and their tissue samples

\begin{tabular}{lllll}
\hline & IDC $(\mathbf{n}=\mathbf{5})$ & ILC $(\mathbf{n}=\mathbf{5})$ & MBC $(\mathbf{n}=\mathbf{5})$ & NCT $(\mathbf{n}=\mathbf{5})$ \\
\hline Age (mean) & 48.4 & 65.8 & 53 & 44.8 \\
Age range & $39-73$ & $47-75$ & $41-71$ & $37-50$ \\
ER-positive & 3 & 4 & 0 & $\mathrm{n} / \mathrm{a}$ \\
PR-positive & 2 & 4 & 0 & $\mathrm{n} / \mathrm{a}$ \\
HER2-positive & 3 & 2 & 0 & $\mathrm{n} / \mathrm{a}$ \\
Node positive & 3 & 3 & 0 & $\mathrm{n} / \mathrm{a}$ \\
Ki-67 expression (range) & $13-68 \%$ & $8-29 \%$ & $\mathrm{n} / \mathrm{a}$ & \\
\hline
\end{tabular}

Specificity of generated polyclonal antibodies was tested by Western blotting of recombinant proteins and confirmed by immunohystochemical analysis of $\mathrm{MBC}$ tumor, which was taken for generation of MBC cDNA library Br502 [37] with depleted against corresponding recombinant proteins polyclonal antibodies. Depletion of polyclonal antibody was performed as follows: antibodies diluted (1:10) in PBS were incubated overnight with correspondent recombinant proteins $(10 \mathrm{mkg})$ transferred on PVDF membranes by standard blotting procedure. Decreasing of the intensity of immunohistochemical staining of Br502 tumor sections, when depleted antibody were used evidenced for specificity of generated polyclonal antibodies compared with undepleted ones.

\section{Immunohistochemical analysis}

Immunohistochemical analysis of breast cancer samples with polyclonal Abs was performed according to standard protocol. Briefly, representative sections of breast tumors were prepared from parafin blocks. Endogenous peroxidase was quenched with $\mathrm{H}_{2} \mathrm{O}_{2}$ (3\%) in $0.01 \%$ PBS. After blocking of non-specific binding with avidin-biotin blocking solution (Vector Laboratories, Burlingame, CA, USA), tissue sections were incubated overnight at $4^{\circ} \mathrm{C}$ with corresponded polyclonal antibodies (1:400). Then, sections were incubated with biotinylated secondary antibodies for $2 \mathrm{~h}$ at room temperature at 1:400 dilutions (goat anti-mouse biotinylated IgG, Sigma, Steinheim, Germany), followed by incubation with avidin-biotinperoxidase complex (Vector Laboratories, Burlingame, CA, USA) for $30 \mathrm{~min}$ at RT and developed with diaminobenzidine solution. Serum from nonimmune mouse was used as negative control. Immunohistochemical staining of all breast cancer and non-cancerous tissue slides was performed during one experiment in equal conditions for each of antigens analyzed. Haematoxylin was used for counterstaining. Standard microscopy was performed using a Zeiss Universal microscope (Zeiss, Germany), and images were captured using digital Axiocam software.

Taking into account the fact that the expression of the studied antigens in normal and tumor breast tissues are poorly studied, we evaluated the staining intensity for each antigen comparing the slides of non-cancerous and cancerous breast tissue samples of different histological types, which were processed with correspondent polyclonal antibody under the same conditions. Tissue slides were analyzed using a four point semi-quantitative scale for nuclear and cytoplasmic optical staining intensity (graded as 3+ (strong), 2+ (moderate), 1+ (weak), 0 (no staining)) and for the percentage of positively stained cells $(0-$ no staining, $1-<10 \%$ of the cells, $2-11-50 \%$

Table 2 Antigens used for generation of polyclonal antibodies

\begin{tabular}{|c|c|c|c|c|c|}
\hline Antigen & Full name & $\begin{array}{l}\mathrm{NCBI} \\
\text { reference }\end{array}$ & DNA fragment, bp & Vector & $\begin{array}{l}\text { MW of recombinant protein, } \\
\mathrm{kDa} \text {, (including tag) }\end{array}$ \\
\hline LGALS3BP & $\begin{array}{l}\text { Homo sapiens lectin, galactoside-binding, soluble, } 3 \\
\text { binding protein }\end{array}$ & NM_005567.2 & $1483-1686$ & $\begin{array}{l}\text { pGEX4T3 } \\
\text { (GST-tag) }\end{array}$ & 35 \\
\hline RAD50 & Homo sapiens RAD50 homolog (S. cerevisiae) & NM_005732.2 & $2552-3374$ & $\begin{array}{l}\text { pET28b } \\
(6 \text { His-tag })\end{array}$ & 44 \\
\hline FAM50A & $\begin{array}{l}\text { Homo sapiens family with sequence similarity } 50 \text {, } \\
\text { member A }\end{array}$ & NM_004699.1 & $76-1095$ & $\begin{array}{l}\text { pGEX4T3 } \\
(\text { GST-tag) }\end{array}$ & 64 \\
\hline RBPJ & $\begin{array}{l}\text { Homo sapiens recombination signal binding protein } \\
\text { for immunoglobulin kappa J region }\end{array}$ & NM_203284.1 & $492-1850$ & $\begin{array}{l}\text { pET28b } \\
(6 \text { His-tag) }\end{array}$ & 50 \\
\hline PABCP4 & $\begin{array}{l}\text { Homo sapiens poly(A) binding protein, cytoplasmic } 4 \\
\text { (inducible form) }\end{array}$ & NM_003819.2 & $927-3052$ & $\begin{array}{l}\text { pET28b } \\
(6 \text { His-tag })\end{array}$ & 67 \\
\hline LRRFIP1 & $\begin{array}{l}\text { Homo sapiens leucine rich repeat (in FLII) interacting } \\
\text { protein } 1\end{array}$ & NM_004735.2 & $417-1804$ & $\begin{array}{l}\text { pET28b } \\
(6 \text { His-tag) }\end{array}$ & 51 \\
\hline
\end{tabular}


of the cells, $3->50 \%$ of the cells). Pathologist marked biologically representative areas, which contained a mean number of 150 cells ( $\min 72-\max 180$ ), percentage of positive cells was assessed as percent of cells exhibiting reactivity as average in 10 fields at high magnification $(x 400)$. The area of interest was selected randomly, excluding stromal cells and artifacts. Staining intensity and percent reactivity were recorded as mean observed in ten high power fields. The same slides were viewed again by each one of 3 month later, independently of the first vision.

\section{Results}

In our previous studies, focused on identification of novel TAAs of medullary breast carcinoma, we found 41 antigens [37], 18 of which had cancer-restricted serological profile as was shown by phage based allogenic serological screening [35]. TAAs identified represent a diverse range of cellular proteins, some of which were shown to be implicated in cancer development, particularly lectin, galactoside-binding, soluble, 3 binding protein (LGALS3BP) [38], double-strand break repair factor RAD50 [39], nuclear protein with unknown function FAM50A [40], poly(A) binding protein cytoplasmic 4 (PABPC4) [41], mediator of Notch signaling RBPJ [42] and transcription factor LRRFIP1 [43]. To characterize their expression profile and subcellular localization in cancer cells of human breast carcinomas and cells of non-cancerous breast tissues immunohistochemical analysis using specific polyclonal antibodies has been performed. For generation of polyclonal antibodies cDNAs of LGALS3BP, RAD50, FAM50A, RBPJ, PABPC4 and LRRFIP1 antigens from $M B C \lambda$ phage cDNA library were cloned in pGEX4T3 and pET28b plasmid vectors in the frame with GST- and His-tags correspondently for further affine purification (Table 2). All recombinant plasmids were expressed in bacteria and their affinity purified recombinant products were used for immunization of mice (Table 2). Specificity of generated antibodies was tested as described in Materials and Methods (data not shown).

Positive staining for LGALS3BP antigen was observed in more than $50 \%$ of all cells in tissue sections of the most breast tumors types and non-cancerous breast tissues (Figure 1), (Table 3). Tumor cells of IDCs and MBCs showed weak nuclear $(1+)$ and moderate $(2+)$ to strong (3+) cytoplasmic staining, while all ILCs showed opposite expression pattern with weak $(1+)$ cytoplasmic and moderate $(2+)$ nuclear staining (Table 4). Notably, strong LGALS3BP staining was observed at the apical

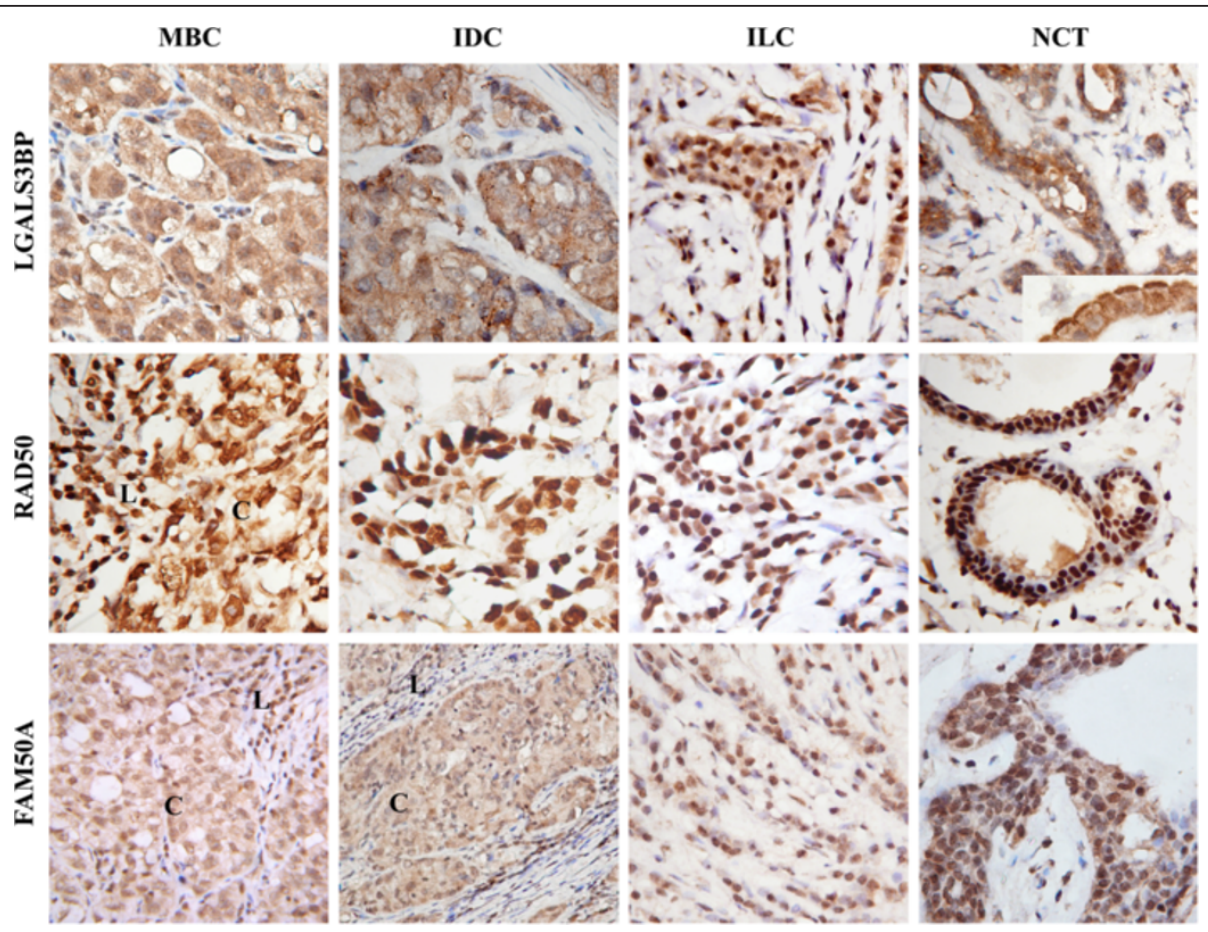

Figure 1 Immunohystochemical staining reaction of LGALS3BP, RAD50, and FAM50A MBC-associated antigens in breast cancer and non-cancerous tissues. Cancer cells of MBC and IDC demonstrated moderate to strong cytoplasmic and weak nuclear LGALS3BP staining, while in ILC samples weak cytoplasmic and moderate nuclear staining was observed. Strong positive LGALS3BP staining of cytoplasm and the apical part of normal epithelial cells was detected. Predominantly strong (3+) nuclear RAD50 staining in normal and cancer cells of MBC, IDC, and ILC was detected. Antigen FAM50A had moderate nuclear and weak cytoplasmic staining in NCT and tumor samples. C - cancer cells, L - lymphocytic infiltrate. Magnification 400x. 
Table 3 Descriptive data of 6 antigens expression in tissue samples

\begin{tabular}{|c|c|c|c|c|c|c|c|c|c|c|c|c|c|}
\hline \multirow[t]{3}{*}{ Antigen } & \multirow{3}{*}{$\begin{array}{l}\text { Tissue } \\
\text { sample }\end{array}$} & \multicolumn{12}{|c|}{ Positive cells (\%) } \\
\hline & & \multicolumn{4}{|c|}{ Normal cells } & \multicolumn{4}{|c|}{ Cancer cells } & \multicolumn{4}{|c|}{ Immune cells } \\
\hline & & 0 & 1 & 2 & 3 & 0 & 1 & 2 & 3 & 0 & 1 & 2 & 3 \\
\hline \multirow[t]{4}{*}{ LGALS3BP } & $\mathrm{MBC}$ & $\mathrm{n} / \mathrm{a}$ & $\mathrm{n} / \mathrm{a}$ & $\mathrm{n} / \mathrm{a}$ & n/a & - & - & $1 / 5$ & $4 / 5$ & - & - & $1 / 5$ & $4 / 5$ \\
\hline & IDC & $\mathrm{n} / \mathrm{a}$ & $\mathrm{n} / \mathrm{a}$ & $\mathrm{n} / \mathrm{a}$ & $\mathrm{n} / \mathrm{a}$ & - & - & $1 / 5^{*}$ & $4 / 5$ & - & - & $1 / 1^{*}$ & - \\
\hline & ILC & $\mathrm{n} / \mathrm{a}$ & $\mathrm{n} / \mathrm{a}$ & $\mathrm{n} / \mathrm{a}$ & $\mathrm{n} / \mathrm{a}$ & - & - & - & $5 / 5$ & - & - & - & - \\
\hline & $\mathrm{NCT}$ & - & - & - & $5 / 5$ & - & - & - & - & - & - & - & - \\
\hline \multirow[t]{4}{*}{ RAD50 } & $M B C$ & $\mathrm{n} / \mathrm{a}$ & $\mathrm{n} / \mathrm{a}$ & $\mathrm{n} / \mathrm{a}$ & n/a & - & - & - & $5 / 5$ & - & - & - & $5 / 5$ \\
\hline & IDC & $\mathrm{n} / \mathrm{a}$ & $\mathrm{n} / \mathrm{a}$ & $\mathrm{n} / \mathrm{a}$ & n/a & - & - & $1 / 5^{*}$ & $4 / 5$ & - & - & - & $1 / 1^{*}$ \\
\hline & ILC & $\mathrm{n} / \mathrm{a}$ & $\mathrm{n} / \mathrm{a}$ & $\mathrm{n} / \mathrm{a}$ & n/a & - & - & - & $5 / 5$ & - & - & - & - \\
\hline & $\mathrm{NCT}$ & - & - & - & $5 / 5$ & - & - & - & - & - & - & - & - \\
\hline \multirow[t]{4}{*}{ FAM50A } & MBC & $\mathrm{n} / \mathrm{a}$ & $\mathrm{n} / \mathrm{a}$ & $\mathrm{n} / \mathrm{a}$ & $\mathrm{n} / \mathrm{a}$ & - & - & - & $5 / 5$ & - & - & $1 / 5$ & $4 / 5$ \\
\hline & IDC & $\mathrm{n} / \mathrm{a}$ & $\mathrm{n} / \mathrm{a}$ & $\mathrm{n} / \mathrm{a}$ & $\mathrm{n} / \mathrm{a}$ & - & - & $1 / 5^{*}$ & $4 / 5$ & - & - & - & $1 / 1^{*}$ \\
\hline & ILC & $\mathrm{n} / \mathrm{a}$ & $\mathrm{n} / \mathrm{a}$ & $\mathrm{n} / \mathrm{a}$ & $\mathrm{n} / \mathrm{a}$ & - & - & $2 / 5$ & $3 / 5$ & - & - & - & - \\
\hline & $\mathrm{NCT}$ & - & - & - & $5 / 5$ & - & - & - & - & - & - & - & - \\
\hline \multirow[t]{4}{*}{ RBPJ } & $\mathrm{MBC}$ & $\mathrm{n} / \mathrm{a}$ & $\mathrm{n} / \mathrm{a}$ & $\mathrm{n} / \mathrm{a}$ & n/a & - & - & - & $5 / 5$ & - & - & - & $5 / 5$ \\
\hline & IDC & $\mathrm{n} / \mathrm{a}$ & $\mathrm{n} / \mathrm{a}$ & $\mathrm{n} / \mathrm{a}$ & $\mathrm{n} / \mathrm{a}$ & - & - & $1 / 5^{*}$ & $4 / 5$ & - & - & - & $1 / 1^{*}$ \\
\hline & ILC & $\mathrm{n} / \mathrm{a}$ & $\mathrm{n} / \mathrm{a}$ & $\mathrm{n} / \mathrm{a}$ & $\mathrm{n} / \mathrm{a}$ & - & - & - & $5 / 5$ & - & - & - & - \\
\hline & NCT & - & - & - & $5 / 5$ & - & - & - & - & - & - & - & - \\
\hline \multirow[t]{4}{*}{ PABPC4 } & $\mathrm{MBC}$ & $\mathrm{n} / \mathrm{a}$ & $\mathrm{n} / \mathrm{a}$ & $\mathrm{n} / \mathrm{a}$ & n/a & - & - & - & $5 / 5$ & - & - & $1 / 5$ & $4 / 57^{* *}$ \\
\hline & IDC & $\mathrm{n} / \mathrm{a}$ & $\mathrm{n} / \mathrm{a}$ & $\mathrm{n} / \mathrm{a}$ & n/a & - & - & $1 / 5^{*}$ & $4 / 5$ & - & - & - & $1 / 1^{*}$ \\
\hline & ILC & $\mathrm{n} / \mathrm{a}$ & $\mathrm{n} / \mathrm{a}$ & $\mathrm{n} / \mathrm{a}$ & n/a & - & - & - & $5 / 5$ & - & - & - & - \\
\hline & $\mathrm{NCT}$ & - & - & - & $5 / 5$ & - & - & - & - & - & - & - & - \\
\hline \multirow[t]{4}{*}{ LRRFIP1 } & $\mathrm{MBC}$ & $\mathrm{n} / \mathrm{a}$ & $\mathrm{n} / \mathrm{a}$ & $\mathrm{n} / \mathrm{a}$ & n/a & - & - & - & $5 / 5$ & - & - & - & $5 / 5$ \\
\hline & IDC & $\mathrm{n} / \mathrm{a}$ & $\mathrm{n} / \mathrm{a}$ & $\mathrm{n} / \mathrm{a}$ & $\mathrm{n} / \mathrm{a}$ & - & - & $1 / 5^{*}$ & $4 / 5$ & - & - & $1 / 1^{*}$ & - \\
\hline & ILC & $\mathrm{n} / \mathrm{a}$ & $\mathrm{n} / \mathrm{a}$ & $\mathrm{n} / \mathrm{a}$ & $\mathrm{n} / \mathrm{a}$ & - & - & - & $5 / 5$ & - & - & - & - \\
\hline & $\mathrm{NCT}$ & - & - & - & $5 / 5$ & - & - & - & - & - & - & - & - \\
\hline
\end{tabular}

MBC - medullary breast carcinoma, IDC-invasive ductal carcinoma, ILC - invasive lobular carcinoma, NCT - non-cancerous tissue; n/a - normal cells were not available within tumor sample; 0 - no staining, $1-<10 \%$ of the positively stained cells, $2-10-50 \%$ of the positively stained cells, $3>50 \%$ of the positively stained cells; * - one case of IDC which was heavily infiltrated by lymphocytes; ** - PABPC4 positive staining was observed in $50-70 \%$ of immune cells.

part of normal epithelial cells of the ducts and lobules in non-cancerous tissues (Figure 1) and in some ILCs cases.

All 15 breast cancer and 5 non-cancerous tissue samples were positive for the DNA reparation factor RAD50 (Figure 1), (Table 3). We observed moderate $(2+)$ to strong $(3+)$ nuclear RAD50 staining with no cytoplasmic staining apparent in normal and cancer cells in the most cases. However, in 4 of 5 ILCs cases decreasing of the intensity of nuclear staining (moderate $(2+)$ ) was detected.

Analysis of FAM50A protein expression revealed that more than $50 \%$ of cells were positively stained in cancer and non-cancerous tissue sets (Figure 1), (Table 3). FAM50A protein predominantly was distributed in nucleus and cytoplasm of cancer cells of all tumor samples with preferentially moderate $(2+)$ and weak $(1+)$ positive staining respectively (Table 4 ).
RBPJ staining was indicated in the most of cancer and normal cells (Figure 2), (Table 3). Moderate $(2+)$ to strong $(3+)$ nuclear and weak (1+) cytoplasmic staining (Table 4) was detected in MBC and IDC tissue samples. In ILC and NCT tissues samples predominantly moderate $(2+)$ nuclear and additional weak $(1+)$ cytoplasmic staining in some cases was detected.

Moderate $(2+)$ to strong $(3+)$ PABPC4 positive staining was exclusively observed in cytoplasm of normal and cancer cells of non-cancerous and cancer tissue samples with no relation to histological type (Figure 2), (Tables 3 and 4).

LRRFIP1 nuclear and cytoplasmic expression was indicated in more than $50 \%$ of all tissue samples (Figure 2), (Table 3). This protein was located in nucleus and cytoplasm of both cancerous and non-cancerous tissue sets with moderate $(2+)$ to strong $(3+)$ nuclear and weak $(1+)$ cytoplasmic staining, however in $\mathrm{MBC}$ tissues moderate 
Table 4 Descriptive data of 6 antigens intracellular distribution and insensitivity of staining in tissue samples*

\begin{tabular}{|c|c|c|c|c|c|c|c|c|}
\hline \multirow[b]{2}{*}{ Case } & \multirow[b]{2}{*}{ Tissue sample } & \multirow[b]{2}{*}{ Age } & \multicolumn{6}{|c|}{ Antigens } \\
\hline & & & LGALS3BP & RAD50 & FAM50A & RBPJ & PABPC4 & LRRFIP1 \\
\hline 1 & $\mathrm{MBC}$ & 42 & $\mathrm{~N} 1+, \mathrm{C} 2+$ & N3+ & $\mathrm{N} 1+, \mathrm{C} 1+$ & $\mathrm{N} 2+, \mathrm{C} 1+$ & $\mathrm{C} 3+$ & $\mathrm{N} 2+, \mathrm{C} 2+$ \\
\hline 2 & $\mathrm{MBC}$ & 40 & $\mathrm{~N} 1+, \mathrm{C} 3+$ & $\mathrm{N} 2+$ & $\mathrm{N} 2+, \mathrm{C} 2+$ & $\mathrm{N} 2+, \mathrm{C} 1+$ & $\mathrm{C} 3+$ & $\mathrm{N} 2+, \mathrm{C} 2+$ \\
\hline 3 & $\mathrm{MBC}$ & 46 & $\mathrm{~N} 1+, \mathrm{C} 3+$ & N3+ & $\mathrm{N} 1+, \mathrm{C} 1+$ & $\mathrm{N} 2+, \mathrm{C} 1+$ & $\mathrm{C} 2+$ & $\mathrm{N} 3+, \mathrm{C} 2+$ \\
\hline 4 & $M B C$ & 70 & $\mathrm{~N} 2+, \mathrm{C} 2+$ & $\mathrm{N} 3+, \mathrm{C} 1+$ & $\mathrm{N} 2+, \mathrm{C} 1+$ & $\mathrm{N} 3+, \mathrm{C} 1+$ & $\mathrm{C} 3+$ & $\mathrm{N} 3+, \mathrm{C} 1+$ \\
\hline 5 & $\mathrm{MBC}$ & 57 & $\mathrm{~N} 1+, \mathrm{C} 3+$ & N3+ & $\mathrm{N} 2+, \mathrm{C} 1+$ & $\mathrm{N} 3+, \mathrm{Cl}+$ & $\mathrm{C} 3+$ & $\mathrm{N} 2+, \mathrm{C} 2+$ \\
\hline 6 & IDC & 66 & $\mathrm{~N} 1+, \mathrm{C} 3+$ & N3+ & $\mathrm{N} 2+, \mathrm{Cl}+$ & $\mathrm{N} 2+, \mathrm{C} 1+$ & $\mathrm{C} 3+$ & $\mathrm{N} 3+, \mathrm{C} 1+$ \\
\hline 7 & IDC & 38 & $\mathrm{~N} 1+, \mathrm{C} 2+$ & $\mathrm{N} 2+$ & $\mathrm{N} 2+, \mathrm{C} 2+$ & $\mathrm{N} 2+, \mathrm{C} 1+$ & $\mathrm{C} 2+$ & $\mathrm{N} 3+, \mathrm{C} 1+$ \\
\hline 8 & IDC & 68 & $\mathrm{~N} 1+, \mathrm{C} 2+$ & N3+ & $\mathrm{N} 2+, \mathrm{C} 1+$ & $\mathrm{N} 3+, \mathrm{C} 2+$ & $\mathrm{C} 3+$ & $\mathrm{N} 2+, \mathrm{C} 1+$ \\
\hline 9 & IDC & 72 & $\mathrm{~N} 1+, \mathrm{C} 2+$ & N3+ & $\mathrm{N} 2+, \mathrm{C} 1+$ & $\mathrm{N} 2+, \mathrm{C} 1+$ & $\mathrm{C} 3+$ & $\mathrm{N} 3+, \mathrm{C} 1+$ \\
\hline 10 & IDC & 63 & $\mathrm{~N} 1+, \mathrm{C} 3+$ & N3+ & $\mathrm{N} 2+, \mathrm{C} 1+$ & $\mathrm{N} 3+, \mathrm{C} 1+$ & $\mathrm{C} 2+$ & $\mathrm{N} 2+, \mathrm{C} 1+$ \\
\hline 11 & ILC & 66 & $\mathrm{~N} 2+, \mathrm{C} 1+$ & $\mathrm{N} 2+$ & $\mathrm{N} 2+, \mathrm{C} 1+$ & $\mathrm{N} 2+, \mathrm{C} 1+$ & $\mathrm{C} 3+$ & $\mathrm{N} 2+$ \\
\hline 12 & ILC & 38 & $\mathrm{~N} 2+, \mathrm{C} 1+$ & N3+ & $\mathrm{N} 2+, \mathrm{C} 1+$ & $\mathrm{N} 2+$ & $\mathrm{C} 2+$ & $\mathrm{N} 3+, \mathrm{C} 1+$ \\
\hline 13 & ILC & 68 & $\mathrm{~N} 2+, \mathrm{C} 1+$ & $\mathrm{N} 2+$ & $\mathrm{N} 2+, \mathrm{C} 1+$ & $\mathrm{N} 2+$ & $\mathrm{C} 3+$ & $\mathrm{N} 3+, \mathrm{C} 1+$ \\
\hline 14 & ILC & 72 & $\mathrm{~N} 2+, \mathrm{C} 1+$ & $\mathrm{N} 2+$ & $\mathrm{N} 2+, \mathrm{C} 1+$ & $\mathrm{N} 2+, \mathrm{C} 1+$ & $\mathrm{C} 2+$ & $\mathrm{N} 2+$ \\
\hline 15 & ILC & 63 & $\mathrm{~N} 2+, \mathrm{Cl}+$ & $\mathrm{N} 2+$ & $\mathrm{N} 2+, \mathrm{C} 1+$ & $\mathrm{N} 2+$ & $\mathrm{C} 3+$ & $\mathrm{N} 3+, \mathrm{C} 1+$ \\
\hline 16 & $\mathrm{NCT}$ & 43 & $\mathrm{~N} 2+, \mathrm{C} 1+$ & N3+ & $\mathrm{N} 2+, \mathrm{C} 1+$ & $\mathrm{N} 1+, \mathrm{Cl}+$ & $\mathrm{C} 3+$ & $\mathrm{N} 2+, \mathrm{C} 1+$ \\
\hline 17 & NCT & 50 & $\mathrm{~N} 1+, \mathrm{C} 2+$ & $\mathrm{N} 3+, \mathrm{Cl}+$ & $\mathrm{N} 3+, \mathrm{C} 1+$ & $\mathrm{N} 2+, \mathrm{C} 1+$ & $\mathrm{C} 3+$ & N3+ \\
\hline 18 & $\mathrm{NCT}$ & 46 & $\mathrm{~N} 1+, \mathrm{C} 2+$ & N3+ & $\mathrm{N} 2+, \mathrm{C} 1+$ & $\mathrm{N} 1+, \mathrm{Cl}+$ & $\mathrm{C} 3+$ & $\mathrm{N} 2+, \mathrm{C} 1+$ \\
\hline 19 & $\mathrm{NCT}$ & 48 & $\mathrm{~N} 2+, \mathrm{Cl}+$ & N3+ & $\mathrm{N} 2+, \mathrm{Cl}+$ & $\mathrm{N} 2+$ & $\mathrm{C} 2+$ & $\mathrm{N} 3+, \mathrm{C} 1+$ \\
\hline 20 & NCT & 37 & $\mathrm{~N} 1+, \mathrm{C} 1+$ & N3+ & $\mathrm{N} 2+, \mathrm{C} 1+$ & $\mathrm{N} 2+$ & $\mathrm{C} 2+$ & N3+ \\
\hline
\end{tabular}

MBC - medullary breast carcinoma, IDC - invasive ductal carcinoma, ILC - invasive lobular carcinoma, NCT - non-cancerous tissue. N - nuclear staining, $C$ - cytoplasmic staining; ${ }^{*}$ staining intensity was graded as $3+$ (strong), $2+$ (moderate), $1+$ (weak).

(2+) cytoplasmic LRRFIP1 staining was observed (Figure 2). According to the literature data some of the analyzed proteins could be involved in modulation of immune response $[41,42,44-46]$. Taking this fact into account we performed immunohistochemical analysis of tumor regions of all MBC and 1 case of IDC highly infiltrated by lypmphocytes, with correspondent polyclonal antibodies. We have shown that all proteins expressed in the most of immune cells of lymphocytic infiltrate (up to 90\%) (Table 3), with exception for PABPC4 which positive staining was observed only in $50-70 \%$ of immune cells (Figure 3). Moreover, PABPC4 showed more intensive cytoplasmic staining of immune cells compared with cancer and normal cells (Figure 3), as well as nuclear antigen with unknown function FAM50A. More intensive compared with cancer and normal cells FAM50A positive staining was detected in the nucleus of immune cells (Figure 3).

\section{Discussion}

The identification of breast cancer markers has been the focus of extensive research in past decades, there still an urgent need for good cancer biomarkers remains. Moreover, characterization of these proteins and identification of the alterations that distinguish cancer cells from normal ones will help to understand the molecular mechanisms of cancerogenesis. In previous study we identified by SEREX-approach 41 novel medullary breast carcinoma autoantigens, 18 of which had cancer-related serological profile [35]. During this study expression pattern of 6 from 18 potential MBC-derived antigens were studied by immunohistochemistry in tissue samples obtained from patients with different histological types of breast cancer and fibrocystic disease using specifically generated polyclonal antibodies. Medullary breast carcinoma, lobular and ductal invasive breast carcinomas' tissue samples were taken for immunohistochemical investigation of expression patterns of above mentioned proteins. It's known that lobular and ductal carcinomas derive both from the breast terminal duct lobular units [47] and the terminology "ductal" and "lobular" is still being used for historical reasons and to date there is no evidence to suggest that these tumors arise from ductal or lobular epithelial cells. Thus, the differences in their morphology are likely to reflect the different mechanisms of carcinogenesis rather than the anatomical origin of the lesions [48]. For example, it was demonstrated that $5.8 \%$ of the transcriptionally regulated genes were differentially expressed in ILCs compared to grade- and molecular subtype-matched IDCs [49]. Identification 


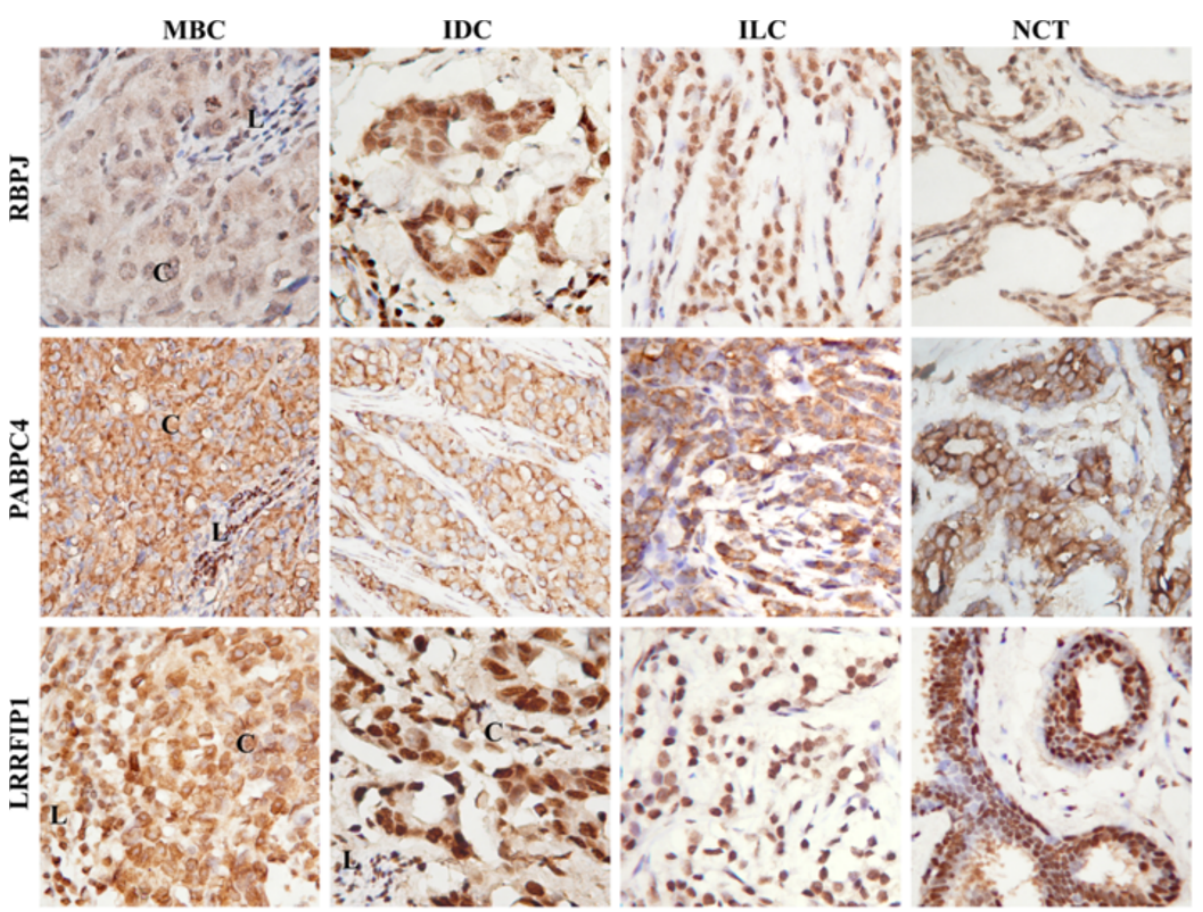

Figure 2 Immunohystochemical staining reaction of RBPJ, PABPC4, and LRRFIP1 MBC-associated antigens in breast cancer and non-cancerous tissues. Antigen RBPJ had moderate nuclear and weak cytoplasmic staining of normal and cancer cells of NCT, MBC, and IDC, except for ILC samples which showed only moderate (2+) nuclear staining. Moderate to strong positive PABPC4 staining was detected in cytoplasm of normal and cancer cells of non-cancerous and cancer tissue samples. Cancer cells of IDC and ILC, and normal cells of non-cancerous tissues had moderate to strong nuclear and weak cytoplasmic LRRFIP1 staining, but in MBC moderate cytoplasmic LRRFIP1 staining was observed. C - cancer cells, L - lymphocytic infiltrate. Magnification 400x.

and characterization of molecular targets specific for each type of breast cancer will help to design more precise therapeutic and diagnostic approaches for curing of this type of malignancy.

During this preliminary study, we investigated expression pattern of $6 \mathrm{MBC}$ autoantigens, including secretory protein LGALS3BP, 2 nuclear proteins (RAD50, FAM50A), one cytoplasmic protein (PABPC4) and 2 tratscription factors (RBPJ, LRRFIP1), in different histological types of breast cancer and non-cancerous tissue samples by immunohistochemical analysis. Despite the fact that automated measurement using digital slide scanners and computer-aid methods are increasingly used for immunohystochemical analysis, during this study we used visual semi-quantitative evaluation of $\mathrm{MBC}$ antigens expression pattern by expert pathologist because high correlation between these two approaches was recently shown [50-52].

It was shown that all analyzed proteins expressed in the most cells of non-cancerous and cancer tissue

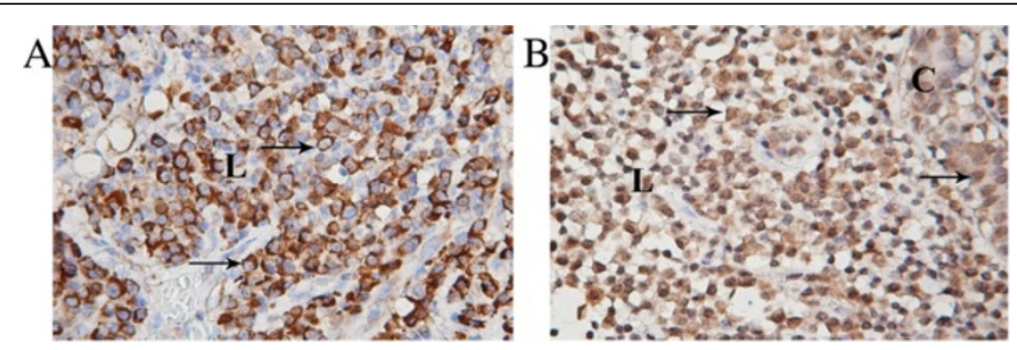

Figure 3 Immunohistochemical staining of PABPC4 (A) and FAM50A (B) antigens in cells of lymphocytic infiltrate of medullary breast carcinoma. Both antigens showed more intensive staining of immune cells compared with cancer cells. Positive cytoplasmic PABPC4 staining was detected only in a part of immune cells. FAM50A showed preferentially nuclear staining in immune cells. Positively stained cells are indicated by arrows. C - cancer cells, L - lymphocytic infiltrate. Magnification 400x. 
samples. However distinct expression pattern was revealed for some antigens in breast carcinomas of different histological types.

LGALS3BP (also known as MAC-2BP and 90K protein) was originally identified as a tumor-associated antigen in the culture supernatant of human breast cancer cells [53]. Early works focused on study of LGALS3BP showed its expression in more than $80 \%$ of breast cancer tissues, but not in non-cancerous normal mammary gland surrounding the cancer cells [53]. Immunohistochemical analysis of LGALS3BP expression in several tumors, including breast carcinomas, revealed LGALS3BP positive staining predominantly in cytoplasm [54]. During our study, we also, observed moderate to strong LGALS3BP positive staining in cytoplasm and weak nuclear staining of IDC and MBC cells. Interestingly, that in ILC tumors we detected opposite pattern of LGALS3BP expression with moderate nuclear and weak cytoplasmic staining. Moreover, during this study we observed an explicit apical membrane staining of LGALS3BP in some of epithelial cells in breast tissues of patients with fibrocystic disease and epithelial cells lining the normal ducts in ILCs, contrary to mentioned above literature data [53]. This strong apical membrane staining of LGALS3BP may partly be explained by its ability to be secreted by different types of cells including epithelial cells [55-57].

RAD50 is a highly conserved DNA double-strand break repair factor [39]. Its aberrantly reduced protein expression was reported in 3\% of breast tumors (predominantly ER/PR/ERBB2 triple-negative and highergrade familial breast tumors) [57]. In our investigation we also showed strong RAD50 nuclear staining of noncancerous and cancer cells. However, in 4 from 5 ILC cases we observed rather moderate than strong RAD50 positive staining in the nucleus of cancer cells. Since, down-regulation of some genes including RAD50 was shown in ILCs [49]; our results partially confirmed the data about reduced RAD50 expression in ILC tumors. However, this fact should to be further investigated on a large number of samples.

FAM50A (also known as XAP5) is a poorly studied protein with unknown function having signal for nuclear localization [40]. Here, we describe for the first time its subcellular localization and expression pattern in cancer and non-cancerous breast tissues. According to our findings FAM50A protein is expressed both in nucleus and cytoplasm in the most cells of cancer and non-cancerous breast tissues without any significant differences. However we found stronger FAM50A nuclear staining in immunocytes compared with cancer and non-cancerous breast cells.

PABPC4 (or inducible PABP (iPABP)) a homolog of PABP, have critical roles in RNA processing beyond simply binding to poly(A) sequences [41]. According to the literature data PABPC4 is a diffusely cytoplasmic protein that can be localized to stress granules [58]; its expression is induced upon stimulation of peripheral $\mathrm{T}$ cells [41]. The fact that induction of PABPC4 coincides with the induction of lymphokine mRNA in activated $T$ cells suggests that perhaps iPABP is necessary for regulation of stability of labile mRNA species [41]. In our study, we observed moderate to strong PABPC4 positive staining in cytoplasm in the most of cancer and normal cells of all tissue samples and in part of immunocytes. One may be speculated that PABPC4 expression can be restricted to activated $\mathrm{T}$ cells at least in $\mathrm{MBC}$ tumors, and possibly contributes to a more effective immune response that can be associated with good prognosis for patients with this tumor type. However, to confirm this assumption additional study has to be performed.

$\mathrm{RBPJ}$ is a primary transcription mediator of canonical Notch signaling [59], which participates in cell fate determination, and is involved in the regulation of tumor behavior in multiple decisions [60]. It has been shown previously, that RBPJ protein can be detected in the nucleus as well as in the cytoplasm and it subcellular distribution changes in defined physiological contexts [61-64].

In all cancer and non-cancerous cases predominantly moderate nuclear RBPJ and weak cytoplasmic staining was detected, however in some MBC and IDC cases strong nuclear staining was revealed. These differences may be associated with histological and molecular features of these tumor types.

LRRFIP1 is ubiquitously expressed and found in the nuclear and cytoplasmic compartments [65]. This protein acts as transcriptional repressor of some genes $[45,46,66]$ and indirectly throught interaction with Flightless 1 protein involved in actin severing, capping and cytoskeletal rearrangement [67]. Notably, LRRFIP1 can be mutated in breast tumors and soft tissue sarcomas [68], and may be involved in the regulation of cell growth [43]. We observed strong nuclear and weak cytoplasmic distribution of LRRFIP1 in cancer and normal cells except for MBC tumors, which showed moderate cytoplasmic staining in addition to strong nuclear staining.

Thus, during this study we described for the first time expression patterns of 6 potential MBC-associated antigens, including LGALS3BP, RAD50, FAM50A, RBPJ, PABPC4, LRRFIP1 in different histological types of breast carcinomas and non-cancerous breast tissues by immunohistochemical analysis. Our data indicate that all 6 antigens predominantly expressed in the most cells of all histological types of breast tumors, non-cancerous tissues, and immunocytes with slight differences in intensity of staining and subcellular localization. The most significant differences were observed for RAD50 and 
LGALS3BP antigens in different histological types of breast carcinomas. During this study we described for the first time expression pattern of poorly studied antigen FAM50A and observed its more intensive nuclear staining in the immune cells compared with cancer and non-cancerous cells. Additionally increased expression of other antigen PABPC4 was observed in restricted number of immune cells infiltrating breast tumors. These observations possibly reflect molecular changes that occur during breast carcinogenesis in different histological types of breast cancer and indicate that RAD50 and LGALS3BP antigens are promising candidates for more comprehensive research as potential molecular markers for breast cancer diagnostics and therapy. Moreover, antigens FAM50A and PABPC4 are intriguing targets for investigation of the features of the immune response in patients with highly infiltrating breast tumors including $\mathrm{MBC}$, which despite anaplastic features has favorable prognosis.

\section{Conclusions}

In this study we determined for the first time expression patterns of 6 potential MBC-associated antigens, including LGALS3BP, RAD50, FAM50A, RBPJ, PABPC4, and LRRFIP1, in non-cancerous cells of the breast, cancer and immune cells of different histological types of breast carcinomas by immunohistochemical analysis. The most significant differences in expression pattern were revealed for RAD50 and LGALS3BP in cancer cells of different histological types of breast cancer and for PABPC4 and FAM50A antigens in immune cells infiltrating breast tumors. This work is a pilot study, which made possible to select 4 potential breast cancer markers (FAM50, PABC4, RAD50, LGALS3BP) for further studies with larger cohorts of patients with different histological types of breast cancer using automated measurement systems for immunohistochemical analysis. Data obtained can contribute to investigations in the field of breast cancer genesis, diagnostics and therapy, and may be of interest for a wide range of researchers including those who already focused on precise study of indicated proteins.

\section{Abbreviations}

SEREX: Serological identification of antigens by recombinant expression cloning; SEPRA: Serological proteome analysis; MAPPing: Multiple affinity protein profiling; TAAs: Tumor-associated antigens; MBC: Medullary breast carcinoma; NCT: Non-cancerous breast tissue; IDC: Invasive ductal carcinoma; ILC: Invasive lobular carcinoma; LGALS3BP: Lectin, galactoside-binding, soluble, 3 binding protein; RAD50: Human RAD50 S. cerevisiae homolog; PABPC4: Poly(A) binding protein, cytoplasmic 4; FAM50A: Family with sequence similarity 50, member A; RBPJ: Recombination signal binding protein for immunoglobulin kappa J region; LRRFIP1: Transcription factor leucine rich repeat (in FLII) interacting protein 1.
}

\section{Competing interests}

The authors declare that they have no competing interests.

\section{Authors' contributions}

OK and SA carried out the experiments and analysis of results obtained. OK, $V F, R G$ participated in the design of the study, analysis of obtained results and drafted the manuscript. All authors have read and approved the final manuscript.

\section{Acknowledgements}

This work was supported by the National Academy of Sciences of Ukraine and State Fund of Fundamental Research of Ukraine (grant №F40.69-2011).

\section{Author details}

'Department of Cell Signaling, Institute of Molecular Biology and Genetics, NAS of Ukraine, 150, Zabolotnogo str., Kyiv, Ukraine. ${ }^{2}$ Educational and Scientific Centre "Institute of Biology", Taras Shevchenko National University of Kyiv, 64, Volodymyrs'ka Str., Kyiv, Ukraine. ${ }^{3}$ Dnipropetrovsk Clinical Oncological Center, Dnipropetrovsk, Ukraine.

Received: 30 August 2012 Accepted: 14 November 2012

Published: 26 November 2012

\section{References}

1. Siegel R, Naishadham D, Jemal A: Cancer statistics. CA Cancer J Clin 2012, 62(1):10-29.

2. Ferlay J, Shin H-R, Bray F: Estimates of world wide burden of cancer in 2008: GLOBOCAN 2008. Int J Cancer 2010, 127(12):2893-2917.

3. Connolly D, Yang Z, Castaldi M, Simmons N, Oktay MH, Coniglio S, Fazzari MJ, Verdier-Pinard P, Montagna C: Septin 9 isoform expression, localization and epigenetic changes during human and mouse breast cancer progression. Breast Cancer Res 2011, 13(4):R76.

4. Chen YT: Identification of human tumor antigens by serological expression cloning: an online review on SEREX. Cancer Immunol 2004, http://www.cance-rimmunity.org/SEREX/.

5. Stockert E, Jager E, Chen YT, Scanlan MJ, Gout I, Karbach J, Arand M, Knuth A, Old LJ: A survey of the humoral immune response of cancer patients to a panel of human tumor antigens. J Exp Med 1998, 187:1349-1354.

6. Devitt G, Meyer C, Wiedemann N, Eichmuller S, Kopp-Schneider A Haferkamp A, Hautmann R, Zoller M: Serological analysis of human renal cell carcinoma. Int J Cancer 2006, 118:2210-2219.

7. Canelle L, Bousquet J, Pionneau C, Deneux L, Imam-Sghiouar N, Caron M, Joubert-Caron R: An efficient proteomics-based approach for the screening of autoantibodies. J Immunol Methods 2005, 299:77-89.

8. Canelle L, Bousquet J, Pionneau C, Hardouin J, Choquet-Kastylevsky G, Joubert-Caron R, Caron M: A proteomic approach to investigate potential biomarkers directed against membrane-associated breast cancer proteins. Electrophoresis 2006, 27:1609-1616.

9. Hardouin J, Lasserre JP, Sylvius L, Joubert-Caron R, Caron M: Cancer immunomics: from serological proteome analysis to multiple affinity protein profiling. Ann N Y Acad Sci 2007, 1107:223-230.

10. Balboni I, Chan SM, Kattah M, Tenenbaum JD, Butte AJ, Utz PJ: Multiplexed protein array plat- forms for analysis of autoimmune diseases. Annu Rev Immunol 2006, 24:391-418.

11. Hudson ME, Pozdnyakova I, Haines K, Mor G, Snyder M: Identification of differentially expressed proteins in ovarian cancer using high-density protein microarrays. Proc Natl Acad Sci U S A 2007, 104:17494-17499.

12. Chen YT, Scanlan MJ, Sahin U, Tureci O, Gure AO, Tsang S, Williamson B, Stockert E, Pfreundschuh M, Old LJ: A testicular antigen aberrantly expressed in human cancers detected by autologous antibody screening. Proc Natl Acad Sci U S A 1997, 94:1914-1918.

13. Wang ET, Sandberg R, Luo S, Khrebtukova I, Zhang L, Mayr C, Kingsmore SF, Schroth GP, Burge CB: Alternative isoform regulation in human tissue transcriptomes. Nature 2008, 456:470-476.

14. Winter SF, Minna JD, Johnson BE, Takahashi T, Gazdar AF, Carbone DP: Development of antibodies against p53 in lung cancer patients appears to be dependent on the type of p53 mutation. Cancer Res 1992, 52:4168-4174

15. Tan HT, Low J, Lim SG, Chung MC: Serum autoantibodies as biomarkers for early cancer detection. FEBS J 2009, 276(23):6880-6904.

16. Utz PJ, Anderson P: Posttranslational protein modifications, apoptosis, and the bypass of tolerance to autoantigens. Arthritis Rheum 1998, 41:1152-1160 
17. Dittmer F, Pohlmann R, Von FK: The phosphorylation pattern of oligosaccharides in secreted procathepsin $D$ is glycosylation site-specific and independent of the expression of mannose 6- phosphate receptors. J Biol Chem 1997, 272:852-858.

18. Hakomori S: Glycosylation defining cancer malignancy: new wine in an old bottle. Proc Natl Acad Sci U S A 2002, 99:10231-10233.

19. Schroeder JA, Masri AA, Adriance MC, Tessier JC, Kotlarczyk KL, Thompson MC, Gendler SJ: MUC1 overexpression results in mammary gland tumorigenesis and prolonged alveolar differentiation. Oncogene 2004, 23:5739-5747.

20. Goodell V, Waisman J, Salazar LG, de la Rosa C, Link J, Coveler AL, Childs JS, Fintak PA, Higgins DM, Disis ML: Level of HER2/neu protein expression in breast cancer may affect the development of endogenous HER-2/neu-specific immunity. Mol Cancer Ther 2008, 7(3):449-454.

21. Yamashita H, Nishio M, Toyama T, Sugiura H, Zhang Z, Kobayashi S, Iwase H: Coexistence of HER2 over-expression and p53 protein accumulation is a strong prognostic molecular marker in breast cancer. Breast Cancer Res 2004, 6(1):R24-R30

22. Thor A, Benz C, Moore D, Goldman E, Edgerton S, Landry J, Schwartz L Mayall B, Hickey E, Weber LA: Stress response protein (srp-27) determination in primary human breast carcinomas: clinical, histologic, and prognostic correlations. J Natl Cancer Inst 1991, 83(3):170-178.

23. Love S, King RJ: A $27 \mathrm{kDa}$ heat shock protein that has anomalous prognostic powers in early and advanced breast cancer. Br J Cancer 1994, 69(4):743-748

24. Yavelsky V, Rohkin S, Shaco-Levy R, Tzikinovsky A, Amir T, Kohn H, Delgado B, Rabinovich A, Piura B, Chan G, Kalantarov G, Trakht I, Lobel L: Native human autoantibodies targeting GIPC1 identify differential expression in malignant tumors of the breast and ovary. BMC Cancer 2008, 8:247.

25. Greene LM, Twal WO, Duffy MJ, McDermott EW, Hill AD, O'Higgins NJ, McCann AH, Dervan PA, Argraves WS, Gallagher WM: Elevated expression and altered processing of fibulin-I protein in human breast cancer. $\mathrm{Br} J$ Cancer 2003, 88(6):871-878.

26. Suzuki H, Graziano DF, McKolanis J, Finn OJ: T cell-dependent antibody responses against aberrantly expressed cyclin B1 protein in patients with cancer and premalignant disease. Clin Cancer Res 2005, 11(4):1521-1526.

27. Arnold A, Papanikolaou A: Cyclin D1 in breast cancer pathogenesis. J Clin Oncol 2005, 23(18):4215-4224.

28. Nielsen NH, Arnerlöv C, Emdin SO, Landberg G: Cyclin E overexpression, a negative prognostic factor in breast cancer with strong correlation to oestrogen receptor status. Br J Cancer 2001, 74(6):874-880.

29. Kao H, Marto JA, Hoffmann TK, Shabanowitz J, Finkelstein SD, Whiteside TL, Hunt DF, Finn OJ: Identification of cyclin B1 as a shared human epithelial tumor-associated antigen recognized by T cells. J Exp Med 2001, 194(9):1313-1323.

30. Ridolfi RL, Rosen PP, Port A, Kinne D, Miké V: Medullary carcinoma of the breast: a clinicopathologic study with 10 year follow-up. Cancer 1977, 40:1365-1385

31. Wargotz ES, Silverberg SG: Medullary carcinoma of the breast: a clinicopathologic study with appraisal of current diagnostic criteria. Hum Pathol 1988, 19:1340-1346.

32. Marginean F, Rakha EA, Ho BC, Ellis IO, Lee AH: Histological features of medullary carcinoma and prognosis in triple-negative basal-like carcinomas of the breast. Mod Pathol 2010, 23:1357-1363.

33. Hsu SM, Raine L, Nayak RN: Medullary carcinoma of breast: an immunohistochemical study of its lymphoid stroma. Cancer 1981, 48:1368-1376.

34. Guo $X$, Fan Y, Lang R, Gu F, Chen L, Cui L, Pringle GA, Zhang X, Fu L: Tumor infiltrating lymphocytes differ in invasive micropapillary carcinoma and medullary carcinoma of breast. Mod Pathol 2008, 21:1101-1107.

35. Kostianets O, Shyian M, Demidov S, Antoniuk S, Gout I, Filonenko V, Kiyamova R: Serological analysis of SEREX-defined medullary breast carcinoma-associated antigens. J Cancer Investig 2012, 7:519-527.

36. Yang XA, Dong XY, Li Y, Wang YD, Chen WF: Purification and refolding of a novel cancer/testis antigen BJ-HCC-2 expressed in the inclusion bodies of Escherichia coli. Protein Expr Purif 2004, 33(2):332-338.

37. Kiyamova R, Kostianets O, Malyuchik S, Filonenko V, Usenko V, Gurtovyy V, Khozayenko Y, Antonuk S, Old L, Gout I: Identification of tumor-associated antigens from medullary breast carcinoma by a modified SEREX approach. Mol Biotechnol 2010, 46(2):105-112.
38. Grassadonia A, Tinari N, lurisci I, Piccolo E, Cumashi A, Innominato P, D'Egidio M, Natoli C, Piantelli M, lacobelli S: $90 \mathrm{~K}$ (Mac-2 BP) and galectins in tumor progression and metastasis. Glycoconj J 2004, 19(7-9):551-556.

39. Dolganov GM, Maser RS, Novikov A, Tosto L, Chong S, Bressan DA, Petrini $\mathrm{JH}$ : Human Rad50 is physically associated with human Mre11: identification of a conserved multiprotein complex implicated in recombinational DNA repair. Mol Cell Biol 1996, 16:4832-4841.

40. Mazzarella R, Pengue G, Yoon J, Jones J, Schlessinger D: Differential expression of XAP5, a candidate disease gene. Genomics 1997 45(1):216-219.

41. Yang $H$, Duckett $C S$, Lindsten T: iPABP, an inducible poly(A)-binding protein detected in activated human T cells. Mol Cell Biol 1995, 15:6770-6776

42. Tanigaki K, Han H, Yamamoto N, Tashiro K, Ikegawa M, Kuroda K, Suzuk A, Nakano T, Honjo T: Notch-RBP-J signaling is involved in cell fate determination of marginal zone B cells. Nat Immun 2002, 3:443-450.

43. Arakawa R, Bagashev A, Song L, Maurer K, Sullivan KE: Characterization of LRRFIP1. Biochem Cell Biol 2010, 88(6):899-906

44. Ullrich A, Sures I, D'Egidio M, Jallal B, Powell TJ, Herbst R, Dreps A, Azam M, Rubinstein M, Natoli C, Shawver LK, Schlessinger J, lacobelli S: The secreted tumor-associated antigen $90 \mathrm{~K}$ is a potent immune stimulator. $J$ Biol Chem 1994, 269:18401-18407.

45. Khachigian LM, Santiago FS, Rafty LA: GC factor 2 represses plateletderived growth factor a-chain gene transcription and is itself induced by arterial injury. Circ Res 1999, 84:1258-1267.

46. Suriano AR, Sanford AN, Kim N, Oh M, Kennedy S, Henderson MJ, Dietzmann K, Sullivan KE: GCF2/LRRFIP1 represses tumor necrosis factor alpha expression. Mol Cell Biol 2005, 25(20):9073-9081.

47. Simpson P, Reis-Filho J, Gale T, Lakhani S: Molecular evolution of breast cancer. J Pathol 2005, 205:248-254.

48. Turashvili G, Bouchal J, Ehrmann J, Fridman E, Skarda J, Kolar Z: Novel immunohistochemical markers for the differentiation of lobular and ductal invasive breast carcinomas. Biomed Pap Med Fac Univ Palacky Olomouc Czech Repub 2007, 151(1):59-64.

49. Weigelt B, Geyer FC, Natrajan R, Lopez-Garcia MA, Ahmad AS, Savage K, Kreike B, Reis-Filho JS: The molecular underpinning of lobular histological growth pattern: a genome-wide transcriptomic analysis of invasive lobular carcinomas and grade- and molecular subtype-matched invasive ductal carcinomas of no special type. J Pathol 2010, 220(1):45-57.

50. Rizzardi AE, Johnson AT, Vogel RI, Pambuccian SE, Henriksen J, Skubitz AP, Metzger GJ, Schmechel SC: Quantitative comparison of immunohistochemical staining measured by digital image analysis versus pathologistvisual scoring. Diagn Pathol 2012, 7:42.

51. Laurinaviciene A, Dasevicius D, Ostapenko V, Jarmalaite S, Lazutka J, Laurinavicius A: Membrane connectivity estimated by digital image analysis of HER2 immunohistochemistry is concordant with visual scoring and fluorescence in situ hybridization results: algorithm evaluation on breast cancer tissue microarrays. Diagn Pathol 2011, 6:87.

52. Krecsák L, Micsik T, Kiszler G, Krenács T, Szabó D, Jónás V, Császár G, Czuni L, Gurzó P, Ficsor L, Molnár B: Technical note on the validation of a semiautomated image analysis software application for estrogen and progesterone receptor detection in breast cancer. Diagn Pathol 2011, 6:6.

53. lacobelli S, Arno E, D'Orazio A, Coletti G: Detection of antigens recognized by a novel monoclonal antibody in tissue and serum from patients with breast cancer. Cancer Res 1986, 46:3005-3010.

54. Lee JH, Zhang X, Shin BK, Lee ES, Kim I: Mac-2 binding protein and galectin-3 expression in mucinous tumours of the ovary: an annealing control primer system and immunohistochemical study. Pathology 2009, 41(3):229-333

55. Rosenberg I, Cherayil BJ, Isselbacher KJ, Pillai S: Mac-2-binding glycoproteins putative ligands for a cytosolic beta-galactoside lectin. J Biol Chem 1991, 266(28):18731-18736.

56. Koths K, Taylor E, Halenbeck R, Casipit C, Wang A: Cloning and characterization of a human Mac-2-binding protein, a new member of the superfamily defined by the macrophage scavenger receptor cysteine-rich domain. J Biol Chem 1993, 268:14245-14249.

57. Bartkova J, Tommiska J, Oplustilova L, Aaltonen K, Tamminen A, Heikkinen T, Mistrik M, Aittomäki K, Blomqvist C, Heikkilä P, Lukas J, Nevanlinna H, Bartek J: Aberrations of the MRE11-RAD50-NBS1 DNA damage sensor complex in human breast cancer: MRE11 as a candidate familial cancer-predisposing gene. Mol Oncol 2008, 2:296-316. 
58. Burgess HM, Richardson WA, Anderson RC, Salaun C, Graham SV, Gray NK: Nuclear relocalisation of cytoplasmic poly(A)-binding proteins PABP1 and PABP4 in response to UV irradiation reveals mRNA-dependent export of metazoan PABPs. J Cell Sci 2011, 124:3344-3355.

59. Alimirah F, Panchanathany R, Davisy FJ, Cheny J, Choubey D: Restoration of p53 expression in human cancer cell lines upregulates the expression of Notch1: implications for cancer cell fate determination after genotoxic stress. Neoplasia 2007, 9:427-434

60. Hu XB, Feng F, Wang YC, Wang L, He F, Dou GR, Liang L, Zhang HW, Liang YM, Han H: Blockade of Notch Signaling in Tumor-Bearing Mice May Lead to Tumor Regression, Progression, or Metastasis, Depending on Tumor Cell Types. Neoplasia 2009, 11(1):32-38.

61. Sakai T, Furukawa T, Iwanari H, Oka C, Nakano T, Kawaichi M, Honjo T: Loss of immunostaining of the RBP-J kappa transcription factor upon F9 cell differentiation induced by retinoic acid. J Biochem 1995, 118(3):621-628.

62. Zhou S, Hayward SD: Nuclear localization of CBF1 is regulated by interactions with the SMRT corepressor complex. Mol Cell Biol 2001, 21(18):6222-6232.

63. Krejcí A, Bray S: Notch activation stimulates transient and selective binding of Su(H)/CSL to target enhancers. Genes Dev 2007, 21(11):1322-1327.

64. Wacker SA, Alvarado C, von Wichert G, Knippschild U, Wiedenmann J, Clauss K, Nienhaus GU, Hameister H, Baumann B, Borggrefe T, Knöchel W, Oswald F: RITA, a novel modulator of Notch signalling, acts via nuclear export of RBP-J. EMBO J 2011, 30(1):43-56.

65. Soler G, Nusbaum S, Varet B, Macintyre EA, Vekemans M, Romana SP, Radford-Weiss I: LRRFIP1, a new FGFR1 partner gene associated with 8p11 myeloproliferative syndrome. Leukemia 2009, 23:1359-1361.

66. Reed AL, Yamazaki H, Kaufman JD, Rubinstein Y, Murphy B, Johnson AC: Molecular cloning and characterization of a transcription regulator with homology to GC-binding factor. J Biol Chem 1998, 273(34):21594-21602.

67. Liu YT, Yin HL: Identification of the binding partners for flightless I, A novel protein bridging the leucine-rich repeat and the gelsolin superfamilies. J Biol Chem 1998, 273(14):7920-7927.

68. Sjöblom T, Jones S, Wood LD, Parsons DW, Lin J, Barber TD, Mandelker D, Leary RJ, Ptak J, Silliman N, Szabo S, Buckhaults P, Farrell C, Meeh P, Markowitz SD, Willis J, Dawson D, Willson JK, Gazdar AF, Hartigan J, Wu L, Liu C, Parmigiani G, Park BH, Bachman KE, Papadopoulos N, Vogelstein B, Kinzler KW, Velculescu VE: The consensus coding sequences of human breast and colorectal cancers. Science 2006, 314(5797):268-274.

doi:10.1186/1746-1596-7-161

Cite this article as: Kostianets et al:: Immunohistochemical analysis of medullary breast carcinoma autoantigens in different histological types of breast carcinomas. Diagnostic Pathology 2012 7:161.

\section{Submit your next manuscript to BioMed Central and take full advantage of:}

- Convenient online submission

- Thorough peer review

- No space constraints or color figure charges

- Immediate publication on acceptance

- Inclusion in PubMed, CAS, Scopus and Google Scholar

- Research which is freely available for redistribution 